UDC 519.766.4

Trofymchuk O. M. ${ }^{1}$, Kozhukhivska O. A. ${ }^{2}$, Bidyuk P. I. ${ }^{3}$, Kozhukhivskyi A. D. ${ }^{4}$

${ }^{1}$ Doctor of technical sciences, professor, deputy director of Institute of telecommunications and information technologies of NAS

Ukraine, Ukraine

2 Candidate of technical sciences, senior teacher, Cherkassy state technological university, Ukraine

3 Doctor of technical sciences, professor, Institute of applied system analysis of National technical university of Ukraine «KPI»,

Ukraine

${ }^{4}$ Doctor of technical sciences, professor of Cherkassy state technological university, Ukraine E-mail: andrejdk@mail.ru

\title{
ESTIMATION OF MARKET RISK IN UKRAINE USING VAR METHODOLOGY
}

\begin{abstract}
The emergence of a market risk due to performing operations with currency can result in substantial financial losses. That is why such situations require carrying out of profound analysis and management of respective risks. The market risk of this kind is characterized with possible losses of financial resources due to incorrectly performed operations with currency. The paper considers the possibility of application of the VaR methodology to the bank currency portfolio using the following methods: delta-normal, as well as the methods of historical modeling and Monte-Carlo simulation. While performing the computing experiments actual data used from the currency market of Ukraine. Quite acceptable results of forecasting possible losses were received by making use of Monte-Carlo simulation that hypothetically can take into account possible variations of the market exchange rates. It was established that the risk forecasting errors appear only due to non-predictable abrupt changes of exchange rates.
\end{abstract}

Keywords: risk measure VaR, bank currency portfolio, historical modeling, Monte-Carlo simulation, delta-normal approach, Ukrainian currency market.

\section{INTRODUCTION}

As far as functioning of financial institutions is closely related to performing of substantial volumes of currency operations the problem naturally arises for performing profound analysis and management of possible financial risks. The currency related risk is a possibility of financial resources loss due to incorrectly performed operations with currency. From the risk management position the banking activities are basically directed towards risk acceptance and getting respective economic compensation instead. Some types of risks represent the price of banking business realization and it is impossible to avoid them completely. That is why the risk management processes is not aiming to complete elimination of the risks. A financial institution should provide a reliable substantiated relation between generalized parameters of possible risks and the capital, available financial resources and financial incomes [1,2].

There exist various approaches to quantitative estimation of possible losses. As of today there are developed the methods for computing of the currency risks that are widely used in financial enterprises. A selection of appropriate computing method is determined by the volume of available information, qualification of personnel that is busy with risk management problems, and the availability of necessary working instrumentation in the form of computer software.
In spite of the fact that such instrumentation market for the financial analysis includes rather wide choice possibilities their cost and the practical usage problems very often result in development of their own software products by the financial institutions. Such systems for risk estimation may exhibit much more functional restrictions that availa than available at the market but their advantages are in the possibility of fast extension of a number of practically needed functions. Also in such cases the financial institution personnel has a possibility to enhance substantially their qualification and to improve existing computing methodologies.

The paper is devoted to application of the VaR methodology for computing possible financial losses in analysis of a currency market with the use of original software.

\section{THE PROBLEM STATEMENT}

The goal of the work is to execute the analysis of influence of exchange rates oscillations on profitability of currency transactions; to present algorithms of calculation of VaR meanings using delta-normal method and also using methods of historical and imitation modeling; to make comparison analysis of using indicated methods of VaR estimation and give recommendations concerning possibilities of their usage on Ukrainian financial market. 


\section{THE INFLUENCE OF EXCHANGE RATES OSCILLATIONS ON PROFITABILITY}

The model of currency matching. Despite the fact that all financial risks in this or that way are implemented on the results of bank activity but the functional connection between risks exists not for all its types. The dependence between size of profits (losses) received as a result of bank holding an open currency line item, and market changes of currency rates is described by a model of currency matching [3]: $\Delta P_{v}=V P\left(s_{p}-s\right)$, where $\Delta P_{v}$ is a profit (loss) received from overestimating of currency money because of currency rate change; $V P$ is a currency line item of a bank; $s_{p}, s-$ predicted and leaking currency rates accordingly.

A currency item (CI) is the indicator of bank's currency risk that is defined by the parity between the amount of assets in certain foreign currency $\left(A_{v}\right)$ and the amount of obligations in that same currency $\left(L_{v}\right): V P=A_{v}-L_{V}$. CI of a bank can be open or closed and be calculated separately for each foreign currency that is included in multicurrency bank briefcase. CI is considered to be open if the amount of assets in foreign currency does not correspond the amount of obligations in that same currency. If the amount of assets in foreign currency is balanced by the amount of obligations in that same foreign currency $\left(A_{v}=L_{v}\right)$, such item is called closed or the item of correspondence. In such case currency risk is almost absent because the rate change of one currency concerning the other will equally influence both the cost of assets and the cost of obligations.

\section{THE ESTIMATION OF CURRENCY RISK VAR USING DELTA-NORMAL METHOD}

In order to demonstrate shortcomings and advantages of a delta-normal method, let's consider how to estimate possible future changes of the cost of briefcase of currency money.

The algorithm of calculation of VaR. The cost of briefcase of currency money $P_{t}$ in base currency is calculated with an expression:

$$
P_{t}=\sum_{i=1}^{N} P_{t}^{i}=\sum_{i=1}^{N} k_{t}^{i} \cdot v_{t}^{i}
$$

where $P_{t}$ - time line of costs of the whole briefcase of currency money in base currency in the moment of time $t$ ( $t=\overline{0, T}$, where $T+1$ - quantity of meanings of time line $\left.P_{t}\right) ; P_{t}^{i}=k_{t}^{i} \cdot v_{t}^{i}-$ the cost of briefcase component in $i$ currency in base currency; $k_{t}^{i}$ - exchange rate of briefcase $i$ currency into base currency on date $t(i=\overline{1, N}$, where $N-$ quantity of currency in briefcase); $v_{i}^{t}-$ the volume of $i$ currency in briefcase on date $t$ (the size of open currency item in terms of currencies). Let's consider the sequence of calculations of risk cost VaR that reflects the possible volume of future changes of the cost of currency money briefcase $P_{t}$.
Stage 1. The calculation of daily change of currency rates. The meaning of daily change of rates of briefcase currencies is calculated with a formula of geometrical profitability:

$$
x_{t}^{i}=\ln \left(\frac{k_{t}^{i}}{k_{t-1}^{i}}\right)
$$

where $k_{t}^{i}$ - the meaning of exchange rate of $i$ currency to base currency on date $t, t=\overline{1, T} ; k_{t-1}^{i}-$ the meaning of exchange rate of $i$ currency to base currency on date $t 1$. Logarithm of time of changes of currency rate characterizes the intensity of change of currency rate and is a random variable, the distributing of which is close to normal with average meaning close to zero.

Stage 2. The calculation of volatility of currencies. In order to calculate the volatility of each currency separately without taking into account its connection with other currencies in briefcase, it is necessary to calculate for each currency selective average and standard quadratic deviation $\sigma^{i}$ time line of its profitability $\left\{x_{t}^{i}\right\}$ with an expression:

$$
\sigma^{i}=\sqrt{\frac{\sum_{i=1}^{T}\left(x_{t}^{i}-\overline{X^{i}}\right)^{2}}{T-1}} .
$$

Stage 3. The estimation of possible losses behind the open currency item in $\boldsymbol{i}$ currency $\boldsymbol{V a R _ { \mathrm { i } }}$. The variable of risk cost $V a R^{i}$ of open item in $i$ currency is calculated with an expression:

$$
V a R^{i}=k_{1-\alpha} P_{t}^{i} \sigma^{i}
$$

If volatility of $i$ currency (1) is defined on daily interval, the risk cost of $\mathrm{VaR}^{i}$ is also interpreted as maximum expected volume of reduction of total cost of a separately taken component of currency briefcase in $i$ currency during one day with possibility $95 \%$ or $99 \%$ depending on the meaning of quantile $k_{1-\alpha}$ in the expression (2).

Stage 4. The calculation of correlation matrix of briefcase currencies. In order to consider mutual correlation of exchange rate of briefcase currencies in the process of VaR calculation it is necessary to find correlation matrix of briefcase currencies. To do this first it is necessary to calculate co variations $C_{i j}$ of possiblecombinations of random variables $\left\{x_{t}^{i}\right\}$ and $\left\{x_{t}^{j}\right\}$ :

$$
C_{i j}=\frac{1}{T} \sum_{t=1}^{T}\left(x_{t}^{i}-\overline{X^{i}}\right) \cdot\left(x_{t}^{j}-\overline{X^{j}}\right) .
$$

And also correlation coefficients $K_{i j}$ of processes $\left\{x_{t}^{i}\right\}$ and $\left\{x_{t}^{j}\right\}: K_{i j}=\frac{C_{i j}}{\sigma_{i} \sigma_{j}}$. 
Square matrix with dimension $n \times n$, in which on $i$ row and $j$ column intersection the element $K_{i j}$ is located, is a correlation matrix of briefcase exchange rates. This matrix is symmetric: $K_{i j}=K_{j i}$ for all $i, j=\overline{1, N}$, and the elements of main diagonal are single.

Stage 5. The calculation of overall estimation of possible losses VaR of total cost of currency briefcase. Overall estimation of possible losses of total cost of currency briefcase VaR is calculated on the basis of risk costs of $V a R^{i}$ of separate currencies of a briefcase and correlation matrix of exchange currency rates:

$$
V a R=\sqrt{\overline{V a R} \cdot\|\mathbf{K}\| \overline{\operatorname{VaR}^{T}}}
$$

where $\overline{\operatorname{VaR}}=\left\|\operatorname{VaR}^{1} \quad \operatorname{VaR}^{2} \quad \ldots \quad \operatorname{VaR}^{N}\right\|$ - vector-line of separate estimations $\operatorname{VaR}^{i}$ of briefcase parts in $i$ currency; $\mathbf{K}$ - correlation matrix of exchange rates of briefcase currencies to base currency. This method assumes daily data updating and logarithm calculation of course growth rates, co variation and correlation matrixes, volatilities, all VaR ${ }^{i}$ estimations.

\section{THE ESTIMATION OF CURRENCY BANK RISK VAR USING THE METHOD OF HISTORICAL MODELING}

First it is necessary to choose the period of time with depth $\mathrm{T}$ (for example, 250 working days). For these days selection is created from daily changes of currency rates for all $N$ parts of currency briefcase:

$$
\Delta k_{t}^{i}=k_{t}^{i}-k_{t-1}^{i}, i=\overline{1, N},
$$

where $k_{t}^{i}$ - the meaning of exchange rate of $i$ currency to base currency on date $t, t=\overline{1, T} ; k_{t-1}^{i}$ - the meaning of exchange rate of $i$ currency to base currency on date $t-1$. For each of $\mathrm{T}$ scenarios of rate changes it is modeled hypothetical rate $k^{*}$ of each currency in future as its current rate $k_{0}$ plus rate growth which corresponds the chosen scenario:

$$
k_{t}^{i *}=k_{i, 0}+\Delta k_{t}^{i}
$$

Then it is conducted the complete revaluation of current currency briefcase according to rates modeled on the basis of historical scenarios, and for each scenario it is calculated how the cost of today (current) currency briefcase (separately according to long and short bank currency item) would change:

$$
\Delta V_{t}=V_{t}^{*}-V_{0}, t=\overline{1, T}
$$

where $V_{0}=\sum_{i=1}^{N} k_{i, 0} \cdot v_{i, 0}-$ current cost of currency briefcase; $v_{i, 0}$ - current volume of $i$ currency in briefcase (the cost of open currency item in currency units); $V_{t}^{*}=\sum k_{i}^{t^{*}} \cdot v_{i, 0}$ the cost of currency briefcase in base currency according to $t$ historical scenario.

Received $T$ changes of briefcase are ranged by falling for long currency item and on the contrary for the short. VaR is defined as maximum loss that is not exceeded in $(1-\alpha) T$ cases, or is equal to absolute variable of change with a number that corresponds integer part of a figure. This method is relatively easy to implement if daily updating data base of all currencies exists. As a rule the more depth of a retrospective that is used for rates modeling, the higher is the accuracy of estimation $\mathrm{VaR}$, but at the same time the bigger is the risk of using out-of-date data.

\section{THE METHOD OF IMITATION MODELING MONTE-CARLO FOR ESTIMATION OF BANK CURRENCY RISKS VAR}

Monte-Carlo method for estimation of currency risk consists in modeling movement path of exchange rate according to chosen stochastic process. In order to calculate the estimation $V_{a R}{ }^{i}$ cost of $i$ part of currency briefcase (open currency item, $i=\overline{1, N}$ ) it is necessary to build the division of modeled costs for this part. To find the line of modeled future costs of $i$ currency item it is necessary to model $K$ future prices according to movement path which is calculated during $n$ steps. The figures $K$ and $n$ are chosen quite big depending on calculating capacities (for example, $500 * 1000)$. The process of estimation VaR can be represented the way:

1. To generate the consequence according to divided random variables $\varepsilon_{1}, \varepsilon_{2}, \ldots, \varepsilon_{n}$.

2. Using retrospective data of depth $L$ of days to find the meaning of daily pr ofitability (change of $i$ rate of currencies) with a formula $x_{l}^{i}=\ln \left(\frac{k_{l}^{i}}{k_{l-1}^{i}}\right), l=\overline{1, L}$. For the received sampling of profitability for $i$ currency to calculate average $\mu$ and mean squared deviation $\sigma$.

3. Starting with current rate of $i$ currency $k_{t}^{i}$ to calculate future modeled prices $k_{t+1}^{i}, k_{t+2}^{i}, \ldots, k_{t+n}^{i}=k_{T}^{i}$ with formulas [2]:

$$
\begin{gathered}
k_{t+1}^{i}=k_{t}^{i}+k_{t}^{i}\left(\mu \Delta t+\varepsilon_{1} \sigma \sqrt{\Delta t}\right), \\
k_{t+2}^{i}=k_{t+1}^{i}+k_{t+1}^{i}\left(\mu \Delta t+\varepsilon_{2} \sigma \sqrt{\Delta t}\right), \\
\cdots \cdots \cdots \cdots \cdots \cdots \cdots \cdots \cdots \cdots \cdots \cdots \cdots \cdots \cdots \cdots \cdots \cdots \cdots \\
k_{t+n}^{i}=k_{t+n-1}^{i}+k_{t+n-1}^{i}\left(\mu \Delta t+\varepsilon_{n} \sigma \sqrt{\Delta t}\right) .
\end{gathered}
$$

4. To calculate the cost of $i$ currency item in base currency (the part of currency briefcase) for $\operatorname{rate} k_{T}^{i}$ : $P_{T}^{i}=k_{T}^{i} \cdot v_{t}^{i}$, where $v_{t}^{i}$ - current volume of $i$ currency item in units of currencies.

5. The steps 3-4 to repeat $K$ times (depending on the quantity of variables). As a result we get a line of meanings: $P_{T}^{i^{1}}, P_{T}^{i^{2}}, \ldots, P_{T}^{i^{K}}$ 
6. The received $K$ costs of $i$ currency item of briefcase are ranged similarly to the method of historical modeling.

The ranged meanings are numbered from 1 to $K$. Let's designate through $P_{T}^{i^{\alpha}}$ the meaning of currency item from this line by a number that is equal to the whole part of a number $(1-\alpha) K$, that means that it corresponds the set level of trust $(1-\alpha)$.

7. To calculate the average of modeled costs:

$$
\overline{P_{T}^{i}}=\frac{\sum_{k=1}^{K} P_{T}^{i^{k}}}{K}
$$

8. To calculate possible losses according to $i$ currency item: $\operatorname{VaR}^{i}=\overline{P_{T}^{i}}-P_{T}^{i^{\alpha}}$.

\section{THE PECULIARITIES OF MODEL VERIFICATION TO ESTIMATE VAR CURRENCY BRIEFCASE USING HISTORICAL DATA}

The further specified operations influence the size of an open currency position and currency risk: (1) - purchase and sale of available and non-cash foreign currency; (2) charge, receiving, payment of foreign currency in a form of profits and losses; (3) - receipt of funds in foreign currency to statute capital; (4) - repayment by a bank of hopeless debt in foreign currency; (5) - formation of reserves in foreign currency; (6) - purchase and sale of inventory items using foreign currency; (7) - other exchange operations with foreign currency [3-7]. To estimate the changes of structure of bank currency item that does not depend on exchange rates oscillations, the index of Paashe is used.

Let's consider that the total cost of currency briefcase $P_{t}$ in base currency on the moment of time $t$ is defined by a formula:

$$
P_{t}=\sum_{i=1}^{N} k_{t}^{i} \cdot\left|v_{t}^{i}\right|
$$

where $P_{t}^{i}=k_{t}^{i} \cdot v_{t}^{i}$ - currency item of a bank according to $i$ currency in base currency. The index of Paashe $J_{v_{i}}$ characterizes the level of influence of structural changes of a currency item on the total volume of currency item taking into account exchange rates on the beginning of a period $[t-1, t][3]$ :

$$
J_{v_{i}}=\frac{k_{t-1}^{i} \cdot v_{t}^{i}}{k_{t-1}^{i} \cdot v_{t-1}^{i}}, i=\overline{1, N}
$$

The process of verification of a model for currency risk estimation is the following. On the moment of time $t$ it is possible to calculate the meaning of actual cost of a briefcase $\Delta_{t}$ and compare it with the meaning of $V a R_{t}$ The peculiarity of comparison consists of necessity to exclude from calculation the factor of change of physical volumes of briefcase currencies as far as the indicator $\operatorname{VaR}$ does not take into account the changes of volumes of each currency in briefcase. Taking this the adequacy check of VaR-model is made in the following sequence:

1. To define $\Delta_{t}^{i}$ as losses from $i$ currency item for a period of time $[t-1, t]$, as disparity between the cost of $i$ currency item on the moment of time $t$ without taking into account the changes of physical structure that occurred on the period $[t-1, t]$ and its cost on the moment of time $t-1$ with a formula:

$$
\Delta_{t}^{i}=\left\{\begin{array}{c}
\left|\frac{P_{t}^{i}}{J_{v i}^{t}}-P_{t-1}^{i}\right|, \text { if } \frac{P_{t}^{i}}{J_{v i}^{t}}-P_{t-1}^{i}<0 \\
0, \text { if } \frac{P_{t}^{i}}{J_{v i}^{t}}-P_{t-1}^{i}>0
\end{array},\right.
$$

where $J_{v_{i}}^{t}$ is calculated according to expression (3) on the moment of time $t$. Then on each moment of time $t$ of a period of back-testing $(t=\overline{1, T})$ it is calculated the loss from exchange rates oscillations for the currency briefcase on the whole:

$$
\Delta V_{t}=\sum_{i=1}^{N} \Delta_{t}^{i}
$$

2. The comparison of daily meanings $V_{a} R_{t}$ and corresponding to them actual changes of briefcase cost $\Delta V_{t}$. The case when the condition is observed $\Delta V_{t}>V a R_{t}$ that means that the cost change is negative (loss) and at the same time in absolute meaning exceeds $V a R$, is called the exceeding of predicted expenses. Then the quantity of cases of exceeding $L$ is calculated.

3. The model adequacy is checked by the parity: $\frac{L}{T}<\alpha$.

\section{THE ANALYSIS OF RESULTS OF ESTIMATION OF LOSSES VAR}

To estimate VaR it has been used bank currency briefcase that consists of three items in three currencies (USA dollar, euro and Russian ruble). To estimate VaR and test models it has been used the following data: (1) - daily meanings of market rates of dollar USA, euro and Russian ruble from 01.01.2006 - 30.06.2010; (2) - daily data of bank rates from three currencies for a period from 01.06.2006 - 30.06.2010; (3) - daily meanings of open bank currency items in three above mentioned currencies for a period from 01.01.2006 30.06.2010.

\section{THE ANALYSIS OF THE RESULTS OF ESTIMATION VAR USING DELTA-NORMAL METHOD}

On the input of a model the market meanings of exchange rates, bank meanings of exchange rates and bank currency items in briefcase currencies are presented. In order to check 
the adequacy of a model the recommendations of Basel committee of bank supervision for different levels of trust $(95 \%, 99 \%$ and $97 \%$ ) have been used. Each three months it is calculated the quantity of mistakes of exchange rate forecast using delta-normal method; it is based on suggestion about normal division of profitability of exchange rates. The depth of retrospective for estimation of standard deviation is 250 days. The depth of retrospective for estimation VaR is also 250 days. The results of verification are brought together in table 1 .

According to table 1 we can see that the model for estimation $V a R$ of currency briefcase using delta-normal method is inadequate. In order to find the reasons of inadequacy of a model the retrospectives that are used to find estimations $\mathrm{VaR}$ are checked on normal division according to Pirson criterion. Profitability for USA dollar rate does not have normal division. Profitability for euro is divided close to normal division, and on some periods has normal division.

As a result of retrospective testing of a model while calculating $\operatorname{VaR}$ for each currency it has been found: if meaning $\chi_{c n}^{2}$ is less according to euro than to USA dollar, then the division of profitability of euro rate is closer to normal than the division of USA dollar. In such case the method gives fewer mistakes of euro forecast than of USA dollar forecast.

It has been found that the losses start exceeding estimation VaR with $95 \%$ level of trust on the period from March 2008 when unpredicted changes of USA dollar and euro rate started to be observed. With $99 \%$ level of trust (which is demanded by Basel committee) the quantity of forecast mistakes starts growing from the end of September 2008. In the period of forced reduction in second - third quarters of 2008 and on the period of 4-th quarter of $2008-$ first quarter of 2009 the model for estimation of risk VaR using method of historical modeling ceases to be adequate.

\section{THE COMPARISON OF METHODS OF ESTIMATION VAR}

In table 2 it is represented the results of back-testing for each of models and is calculated the quantity of mistakes according to the results of models work on some periods with duration of 250 days each.

The results of analysis of shortages and advantages of used methods of estimation VaR are gathered in table 3 .

\section{CONCLUSIONS}

Measure $\operatorname{VaR}$ has shortages and advantages, but it gives possibility to estimate the risk uniquely for each country and each bank. To compare the results of implementation of this methodology on Ukrainian currency market three methods of estimation VaR of bank currency briefcase are represented.

The model of risks estimation on the base of delta-normal method has appeared to be inadequate because the assumption about the normal division of currency rates profitability hasn't been made. It is necessary to mark that the division of profitability of euro rate on some periods is close to normal and thus the model of estimation VaR of currency item to euro on these periods has appeared to be adequate.

The method of historical modeling has shown satisfactory result only on conditions of stable market situation. It badly adapts to different oscillations on the market and thus today it can't be used on Ukrainian financial market.

The better results of estimation of possible losses have been received using Monte Carlo method. The mistakes in forecasts of possible losses appear only on condition of unpredicted sharp shifts of rate but the model on the base of this method quickly adapts to market changes. To use this method on-line it is necessary to have big calculation capacities that mean vain charges for banks with little market

Table 1. The results of conduction of retrospective testing of calculation VaR using delta-normal method

\begin{tabular}{|c|c|c|c|c|c|c|}
\hline \multirow{2}{*}{ Period } & \multicolumn{7}{|c|}{ The results of back - testing } & \multicolumn{2}{|c|}{ 97 \% } & \multicolumn{2}{c|}{ 99 \% } \\
\cline { 2 - 7 } & $\begin{array}{c}\text { Quantity of } \\
\text { exceeding }\end{array}$ & $\begin{array}{c}\text { \% correct } \\
\text { forecasts }\end{array}$ & $\begin{array}{c}\text { Quantity of } \\
\text { exceeding }\end{array}$ & $\begin{array}{c}\text { \%orrect } \\
\text { forecasts }\end{array}$ & $\begin{array}{c}\text { Quantity of } \\
\text { exceeding }\end{array}$ & $\begin{array}{c}\% \text { correct } \\
\text { forecasts }\end{array}$ \\
\hline $\begin{array}{c}\text { from 21.03.06 to } \\
21.03 .07\end{array}$ & 13 & $94,80 \%$ & 8 & $96,80 \%$ & 3 & $98,80 \%$ \\
\hline $\begin{array}{c}\text { from 20.06.06 to } \\
21.06 .07\end{array}$ & 16 & $93,60 \%$ & 7 & $97,20 \%$ & 4 & $98,40 \%$ \\
\hline $\begin{array}{c}\text { from 22.09.06 to } \\
21.09 .07\end{array}$ & 16 & $93,60 \%$ & 8 & $96,80 \%$ & 6 & $97,60 \%$ \\
\hline $\begin{array}{c}\text { from 21.12.06 to } \\
21.12 .07\end{array}$ & 21 & $91,60 \%$ & 9 & $96,40 \%$ & 6 & $97,60 \%$ \\
\hline $\begin{array}{c}\text { from 23.03.07 to } \\
21.03 .08\end{array}$ & 30 & $88,00 \%$ & 20 & $92,00 \%$ & 15 & $94,00 \%$ \\
\hline $\begin{array}{c}\text { from 24.09.07 to } \\
22.09 .08\end{array}$ & 57 & $77,20 \%$ & 51 & $79,60 \%$ & 40 & $84,00 \%$ \\
\hline $\begin{array}{c}\text { from 24.12.07 to } \\
22.12 .08\end{array}$ & 65 & $74,00 \%$ & 62 & $75,20 \%$ & 49 & $80,40 \%$ \\
\hline $\begin{array}{c}\text { from 20.03.08 to } \\
30.03 .09\end{array}$ & 62 & $75,20 \%$ & 58 & $76,80 \%$ & 42 & $83,20 \%$ \\
\hline
\end{tabular}


Table 2. Comparative analysis of back-testing of a model of risk estimation VaR using different methods

\begin{tabular}{|c|c|c|c|c|c|c|c|}
\hline \multirow{3}{*}{\multicolumn{2}{|c|}{ Period }} & \multicolumn{6}{|c|}{ Results of back-testing with $95 \%$ level of trust } \\
\hline & & \multicolumn{2}{|c|}{ Delta-normal method } & \multicolumn{2}{|c|}{$\begin{array}{c}\text { Method of historical } \\
\text { modeling }\end{array}$} & \multicolumn{2}{|c|}{ Monte Carlo method } \\
\hline & & $\begin{array}{l}\text { Quantity of } \\
\text { exceeding }\end{array}$ & $\begin{array}{l}\text { \% correct } \\
\text { forecasts }\end{array}$ & $\begin{array}{l}\text { Quantity of } \\
\text { exceeding }\end{array}$ & $\begin{array}{l}\text { \% correct } \\
\text { forecasts }\end{array}$ & $\begin{array}{l}\text { Quantity of } \\
\text { exceeding }\end{array}$ & $\begin{array}{l}\text { \% correct } \\
\text { forecasts }\end{array}$ \\
\hline $\begin{array}{l}\text { from } \\
21.03 .06\end{array}$ & to 21.03 .07 & 13 & $94,80 \%$ & 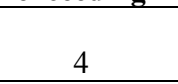 & $98,40 \%$ & 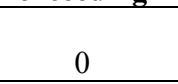 & $100,00 \%$ \\
\hline $\begin{array}{l}\text { from } \\
20.06 .06 \\
\end{array}$ & to 21.06 .07 & 16 & $93,60 \%$ & 5 & $98,00 \%$ & 0 & $100,00 \%$ \\
\hline $\begin{array}{l}\text { from } \\
22.09 .06\end{array}$ & to 21.09 .07 & 16 & $93,60 \%$ & 3 & $98,80 \%$ & 0 & $100,00 \%$ \\
\hline $\begin{array}{l}\text { from } \\
21.12 .06\end{array}$ & to 21.12 .07 & 21 & $91,60 \%$ & 5 & $98,00 \%$ & 0 & $100,00 \%$ \\
\hline $\begin{array}{l}\text { from } \\
23.03 .07\end{array}$ & to 21.03 .08 & 30 & $88,00 \%$ & 16 & $93,60 \%$ & 0 & $100,00 \%$ \\
\hline $\begin{array}{l}\text { from } \\
22.06 .07\end{array}$ & to 23.06 .08 & 47 & $81,20 \%$ & 35 & $86,00 \%$ & 3 & $98,80 \%$ \\
\hline $\begin{array}{l}\text { from } \\
24.09 .07\end{array}$ & to 22.09 .08 & 57 & $77,20 \%$ & 50 & $80,00 \%$ & 4 & $98,40 \%$ \\
\hline $\begin{array}{l}\text { from } \\
24.12 .07\end{array}$ & to 22.12 .08 & 65 & $74,00 \%$ & 74 & $70,40 \%$ & 7 & $97,20 \%$ \\
\hline $\begin{array}{l}\text { from } \\
20.03 .08\end{array}$ & to 30.03 .09 & 62 & $75,20 \%$ & 77 & $69,20 \%$ & 7 & $97,20 \%$ \\
\hline
\end{tabular}

Table 3. Comparative analysis of work of different methods for risk estimation VaR

\begin{tabular}{|c|c|c|c|}
\hline $\begin{array}{ll}\text { Criteria } & \text { Method } \\
\end{array}$ & Delta normal & Historical modeling & $\begin{array}{c}\text { Method of imitation modeling } \\
\text { of Monte Carlo }\end{array}$ \\
\hline Estimation & Local & Total & Total \\
\hline $\begin{array}{l}\text { Taking into account } \\
\text { historical division }\end{array}$ & $\begin{array}{c}\text { As estimation of normal } \\
\text { division }\end{array}$ & $\begin{array}{c}\text { The similar to that in } \\
\text { the past }\end{array}$ & Totally \\
\hline $\begin{array}{c}\text { Taking into account } \\
\text { «admissible» volatility }\end{array}$ & Possible & No & Yes \\
\hline $\begin{array}{l}\text { Assumption about } \\
\text { normal division of } \\
\text { profitability }\end{array}$ & Yes & No & No \\
\hline $\begin{array}{c}\text { Estimation of extreme } \\
\text { events }\end{array}$ & $\mathrm{Bad}$ & $\mathrm{Bad}$ & Possible \\
\hline Model risk & Can be great & Admissible & High \\
\hline Volume of retrospective & Average & Very big & Little \\
\hline Calculation difficulty & Not high & High & Very high \\
\hline Visualization & Average & High & High \\
\hline Calculation capacities & Low & Average & High \\
\hline
\end{tabular}

risk. For these banks it is recommended to use standard approach on the base of fixed coefficients to estimate financial risks. To estimate improbable sharp oscillations of currencies (costs, quoting) it is recommended to use stresstesting that gives representation about the volume of losses in crisis market phenomena.

\section{SPISOK LITERATURY}

1. Лобанов, А. А. Энциклопедия финансового риск-менеджмента / А. А. Лобанов, А. В. Чугунов. - М. : Альпина Паблишер, 2003. - 786 c.

2. Jorion, $P h$. Financial risk-management: Second edition / $\mathrm{Ph}$. Jorion. - Hoboken, New Jersey: John Wiley \& Sons, 2003. $-708 \mathrm{p}$. 
3. Управління банківськими ризиками : навч. посібник / [Примостка Л. О., Чуб П. М., Карчева Т. Г. та ін.]; за ред. Примостки О. Л. - К. : КНЕУ, 2007. - 600 с.

4. Методичні вказівки з інспектування банків «Система оцінки ризиків» / Затв. постановою правління Національного банку України від 15.03.2004 № 104.- 2004. - 43 с.

5. Базельский комитет по банковскому надзору. Международная конвергенция измерения капитала и стандартов капитала: новые подходы. - Базель, 2004. http://www.cbr.ru
6. Яблоков, А. I. Методика оцінювання та управління валютним ризиком $\mathrm{VaR} / \mathrm{A}$. I. Яблоков // Економіко-математичне моделювання соціально-економічних систем. - 2007. № 13. - С. 121-128.

7. Милосердов, А. А. Рыночные риски: формализация, моделирование, оценка качества моделей / А. А. Милосердов, Е. Б. Герасимова. - Тамбов : Изд-во Тамбовского гос. техн. ун-та, 2004. $-116 \mathrm{c}$.

Стаття надійшла до редакції 28.10.2013.

Трофимчук А. Н. ${ }^{1}$, Кожуховская О. А. ${ }^{2}$, Бидюк П. И. ${ }^{3}$, Кожуховский А. Д. ${ }^{4}$

'Д-р техн. наук, професор, Институт телекоммуникаций и информационных технологий НАН Украины, Украина

${ }^{2}$ Канд. техн.наук, ст. преп., Черкасский государственный технологический университет, Украина

${ }^{3}$ Д-р техн. наук, профессор, Институт прикладного системного анализа Национального технического университета Украины «КПИ»,Украина

${ }^{4}$ Д-р техн. наук, профессор Черкасский государственный технологический университет, Украина

\section{ОЦЕНКА РЫНОЧНОГО РИСКА В УКРАИНЕ ПО МЕТОДОЛОГИИ VАR}

B работе рассматривается возможность применения методов оценивания меры риска VaR к банковскому валютному портфелю с использованием таких методов: дельта-нормальный, исторический и имитационного моделирования. Приемлемые по качеству результаты прогнозирования возможных потерь получены по методу Монте-Карло, который гипотетически может учитывать возможные изменения курсов валют на рынке. Установлено, что ошибки прогнозов возможных потерь могут возникать только вследствие резких непредвиденных изменений курсов валют.

Ключевые слова: мера риска $\mathrm{VaR}$, банковский валютный портфель, историческое моделирование, имитационное моделирование по методу Монте-Карло, дельта-нормальный метод, украинский валютный рынок.

Трофимчук О. М. ${ }^{1}$, Кожухівська О. А. ${ }^{2}$, Бідюк П. I. ${ }^{3}$, Кожухівський А. Д. ${ }^{4}$

'Д-р техн. наук, професор, Інститут телекомунікацій та інформаційних технологій НАН Україна

${ }^{2}$ Канд. техн.наук, ст.викл., Черкаський державний технологічний університет, Україна

${ }^{3}$ Д-р техн. наук, професор, Інститут прикладного системного аналізу Національного технічного університету України «КПІ», Україна

${ }^{4}$ Д-р техн. наук, професор, Черкаський державний технологічний університет, Україна

\section{ОЦІНКА РИНКОВОГО РИЗИКУ В УКРАЇНІ ЗА МЕТОДОЛОГІЄЮ VAR}

B роботі розглядається можливість застосування методів оцінювання міри ризику VaR для банківського валютного портфеля з використанням таких методів: дельта-нормальний, історичний та імітаційного моделювання. Прийнятні за якістю результати прогнозування втрат отримано за методом Монте-Карло, який гіпотетично може враховувати можливі зміни курсів валют на ринку. Встановлено, що похибки прогнозів можливих втрат виникають лише за наявності непередбачуваних різких змін курсу валют.

Ключові слова: міра ризику VaR, банківський валютний портфель, історичне моделювання, імітаційне моделювання за методом Монте-Карло, дельта-нормальний метод, український валютний ринок.

\section{REFERENCES}

1. Lobanov A. A., Chugunov A. V. E'nciklopediya finansovogo risk-menedzhmenta. Moscow, Alpina Pablisher, 2003, $786 \mathrm{p}$.

2. Jorion $\mathrm{Ph}$. Financial risk-management: Second edition. Hoboken, New Jersey, John Wiley \& Sons, 2003, 708 p.

3. Primostka L. O., Chub P. M., Karcheva T.G. ta in.; za red. Primostky L.O Upravlinnya bankivskymy rysykamy : navch. Posibnyk. Kyiv, KNEU, 2007, 600 p.

4. Metodychni vkazivky z inspektuvannya banкiv «Systema оzіпку rysykiv». Zaтv. posтanovoiu pravlinnia Nazionalnogo banku Uкrainy vid 15.03.2004 № 104, 2004, 43 p.
5. Вazelsкij коmitet po bапкоvsкоти nadzoru. Mezhdunarodnaya коnvergensiya izmereniyа карitala i standartov карitala: novy'е podhody', Bazel, 2004. http://www.cbr.ru

6. Yablokov A. I. Metodyка ozinyuvannya ta upravlinnya valiutnim ryzykom VaR, E'копотіко-matematychne modeliuvannia sotsialno-екоnomichnyh system, 2007, No. 13, pp. 121-128.

7. Miloserdov A. A., Gerasimova E. B. Ry'nochny'e risкi: formalizaciya, modelirovanie, осепка касhestva modelej. Tambov: Izd-vo Tambovsкogo gos. tehn. un-ta, 2004, 116 p. 